\title{
Pengaruh Keberadaan TPA terhadap Kualitas Air Bersih Diwilayah Pemukiman Warga Sekitar: Studi Literatur
}

\author{
Ahmad Walid ${ }^{1}$, Raden Gamal Tamrin Kesumah ${ }^{2}$, Erik Perdana Putra ${ }^{3}$, Puji Suciarti $^{4}$, Wira Herlina $^{5}$ \\ 1,2,3,4,5 Program Studi Tadris Ilmu Pengetahuan Alam, IAIN Bengkulu, Bengkulu Indonesia \\ 1,2,3,4,5 Fakultas Tarbiyah dan Tadris, IAIN Bengkulu, Jalan Raden Fatah, Pagar Dewa, Bengkulu 38211, Indonesia \\ Correspondence email: ahmadwalid@iainbengkulu.ac.id; raden@iainbengkulu.ac.id; erik.perdana@iainbengkulu.ac.id; \\ pujisuciarti1@gmail.com; herlinawira75@gmail.com
}

\begin{abstract}
Abstrak. Pengaruh dengan adanya TPA dengan adanya pecemaran dapat terjadi di udara sebagai akibat dekomposisi sampah, dapat pula mencemari air dan tanah yang disebabkan oleh adanya rembesan leachate Tumpukan sampah dapat menimbulkan kondisi lingkungan fisik dan kimia menjadi tidak sesuai dengan kondisi normal.metode penelitian ini menggunakan metode studi literatur dengan pengumpulan data-data dengan mencari referensi referensi yang relevan dan fakta untuk mendapatkan deskripsi argumentatif tentang pengaruh TPA, Literatur tersebut disaringkan dan dihubungkan untuk mendapatkan kesimpulan yang untuk memahami dampak dari adanya TPA terhadap kualitas air bersih di lingkungan sekitar.hasil yang didapat dan disimpulkan kota yang ditimbun di tempat pemrosesan akhir (TPA), berpotensi menyebabkan pencemaran terhadap lingkungan baik pencamaran air permukaan dan air tanah maupun pencemaran tanah karena adanya air lindi.
\end{abstract}

Kata kunci: TPA; Kualitas Air

Abstract. The influence of the presence of landfill in the presence of pollution can occur in the air as a result of waste decomposition, can also pollute water and soil caused by leachate seepage. Piles of garbage can cause physical and chemical environmental conditions to be incompatible with normal conditions. This research method uses a study method literature by collecting data by looking for relevant references and facts to get an argumentative description of the effect of the landfill, the literature is filtered and connected to get conclusions to understand the impact of the presence of landfill on the quality of clean water in the surrounding environment. result obtained and concluded cities which are stockpiled at the final processing site (TPA), have the potential to cause environmental pollution, both surface and ground water pollution and soil pollution due to leachate.

Keywords: TPA, Water Quality

\section{PENDAHULUAN}

Air merupakan salah satu elemen terpenting bagi kehidupan makhluk hidup di bumi. Air merupakan kebutuhan yang sangat vital bagi kehidupan dan sumber dasar untuk kelangsungan kehidupan di atas bumi. Keberadaan air mutlak diperlukan karena kehidupan di bumi tidak dapat berlangsung tanpa adanya air (Sanropie dkk, 1984). Air memiliki banyak manfaat bagi keberlangsungannya makhluk hidup. Namun yang ada di alam bukanlah didapat sebagai air murni, melainkan sebagai air yang mengandung bermacam-macam zat, baik yang terlarut ataupun tersuspensi. Jenis zat tersebut tergantung dari kondisi lingkungan sekitar sumbernya. Kelestarian lingkungan biasanya selalu dikaitkan dengan pencemaran, berbicara mengenai masalah pencemaran tidak akan terlepas dari masalah kelestarian lingkungan. Hal ini terjadi terutama di kota-kota besar yang disebabkan oleh adanya sampah yang akan berdampak negatif terhadap lingkungan sekitarnya seperti pemandangan tidak sedap, bau busuk, tercemarnya air dan tanah oleh limbah buangan, juga menjadi wadah perkembangan penyakit menular dan lain-lain. Sampah mempunyai potensi untuk menimbulkan pencemaran dan menimbulkan masalah bagi kesehatan. Pencemaran dapat terjadi di udara sebagai akibat dekomposisi sampah, dapat pula mencemari air dan tanah yang disebabkan oleh adanya rembesan leachate Tumpukan sampah dapat menimbulkan kondisi lingkungan fisik dan kimia menjadi tidak sesuai dengan kondisi normal. Hal ini dapat menyebabkan kenaikan suhu dan perubahan $\mathrm{pH}$ tanah maupun air yang menjadi terlalu asam atau basa. Sampah didefinisikan sebagai semua bentuk limbah berbentuk padat yang berasal dari kegiatan manusia dan hewan kemudian dibuang karena tidak bermanfaat atau keberadaannya tidak diinginkan lagi (Tchobanoglous, 1993). Sampah padat tersebut kebanyakan beracun karena mengandung zat-zat kimia industry yang membutuhkan penangan khusus sehingga tidak memberi dampak kepada lingkungan, Anomin (2008). Tumpukan sampah dapat menjadi sarang atau tempat berkembang biak bagi berbagai vector penyakit, misalnya : lalat, tikus, nyamuk, dan lain sebagainya, sehingga dapat menimbulkan penyakit. Purwendro \& Nurhidayat, (2006) Pembusukan sampah ini juga akan menghasilkan air lindi (leachate) yang akan berpotensi mencemari airtanah. Untuk itu perlu adanya pengelolaan sampah yang optimal khususnya dalam pengolahan air lindi. 


\section{METODE}

Dalam peelitian ini menggunakan metode studi literatur dengan pengumpulan data-data dengan mencari referensi referensi yang relevan dan fakta dari buku, jurnal ilmiah, kamus maupun bahan-bahan yang terpercaya dari website yang telah diteliti sebelumnya.Literatur tersebut kemudian disarikan dan dihubungkan untuk memperoleh deskripsi tentang tema kajian.

\section{HASIL DAN PEMBAHASAN \\ Pencemaran Lingkungan}

Pengertian mengenai pencemaran lingkungan dalam Undang-undang No. 32 Tahun 2009, Pencemaran lingkungan hidup adalah masuk atau dimasukkannya makhluk hidup, zat, energi, dan komponen lain ke dalam lingkungan hidup oleh kegiatan manusia sehingga melampaui baku mutu lingkungan hidup yang telah ditetapkan.

Materi pencemar yang biasanya terbentuk atau hadir (turunan sampah) di lingkungan TPA yaitu air lindi (leachate), selayaknya benda cair air lindi akan mengalir ke tempat yang lebih rendah. Air lindi dapat merembes ke dalam tanah dan bercampur dengan air tanah, ataupun mengalir di permukaan tanah dan bermuara pada aliran air sungai. Kemampuan leachate mencemari air permukaan/air tanah dipengaruhi oleh kondisi geologi (type tanah dan jenis batuan) serta kondisi hidrologi (kedalaman dan pergerakan air tanah, jumlah curah hujan serta pengendalian aliran permukaan) dimana lokasi TPA berada (Maramis, 2008).

\section{Sampah}

Sampah menurut Ichsan (1979) merupakan segala zat padat, semi padat yang tak berguna lagi atau terbuang, baik yang dapat membusuk ataupun yang tidak dapat membusuk. Berdasarkan definisi sampah tersebut di atas maka dapat dikatakan bahwa sampah adalah bahan-bahan hasil dari kegiatan masyarakat umum yang tidak digunakan lagi, yang pada umumnya berupa benda padat, baik yang mudah membusuk maupun yang tidak mudah membusuk, kecuali kotoran yang keluar dari tubuh manusia, yang ditinjau dari segi sosial ekonomi sudah tidak berharga, dari segi keindahan dapat mengganggu dan mengurangi nilai estetika dan dari segi lingkungan dapat menyebabkan pencemaran atau gangguan kelestarian lingkungan.

\section{Tempat Pemrosesan Akhir atau (TPA)}

Adalah suatu areal yang menampung sampah dari hasil pengangkutan dari Tempat Pembuangan Sampah (TPS) maupun langsung dari sumbernya (bak/tong sampah) dengan tujuan akan mengurangi permasalahan kapasitas/timbunan sampah yang ada dimasyarakat (Suryono dan Budiman, 2010). Menurut undang-undang No. 18 Tahun 2008 tentang pengelolaaan sampah.
Tempat pemprosesan akhir (TPA) adalah tempat untuk memroses dan mengembalikan sampah ke media lingkungan secara aman bagi manusia dan lingkungan. Tempat pengolahan sampah terpadu adalah tempat dilaksanakannya kegiatan pengumpulan, pemilahan, penggunaan ulang, pendauran ulang, pengolahan, dan pemrosesan akhir sampah. Tempat Pemrosesan Akhir (TPA) merupakan kegiatan akhir dalam mengelola sampah. Tempat pemrosesan akhir ini harus memenuhi persyaratan sebagai berikut:

1) tercakup dalam tata ruang kota, 2) jenis tanah harus kedap air, 3) tanah yang tidak produktif untuk pertanian, 4) dapat digunakan minimal 5-10 tahun, 5) bukan daerah yang potensial untuk mencemari sumber air, 6) jarak dari daerah pusat pelayanan kurang lebih 10 $\mathrm{km}, 7$ ) merupakan daerah bebas banjir, (Kementerian Lingkungan Hidup, 2004).

\section{Lindi}

Sampah di TPA akan mengalami proses penguraian secara kimia dan biokimia. Masalah akan timbul ketika air hujan dan air permukaan meresap ke dalam timbunan sampah industri. Ditambah lagi dengan penguraian sampah secara kimia dan biokimia, akan menimbulkan cairan rembesan dengan kandungan padatan dan kebutuhan oksigen yang sangat tinggi dan kemudian bercampur dengan air hujan, cairan ini disebut dengan lindi (Martono, 1996). Air lindi pada umumnya mengandungsenyawa-senyawa organik dan anorganik yang tinggi. Selayaknya benda cair, air lindi akan mengalir ke tempat yang lebih rendah. Air lindi ini dapat merembes masuk ke dalam tanah dan bercampur dengan air tanah sampai pada jarak 200 meter, ataupun mengalir di permukaan tanah dan bermuara pada aliran air sungai. Secara langsung air tanah atau air sungai tersebut akan tercemar. Air lindi juga dapat mencemari sumber air minum pada jarak 100 meter dari sumber pencemaran (Mahardika, 2010). Air Permukaan Menurut Undangundang No. 7

\section{Air Bersih}

Berdasarkan Peraturan Menteri Kesehatan Republik Indonesia Nomor 416/MENKES/PER/IX/1990 dijelaskan bahwa air adalah air minum, air bersih, air kolam renang dan air pemandian umum. Selanjutnya air minum adalah air yang kualitasnya memenuhi syarat kesehatan dan dapat langsung diminum. Sedangkan air bersih adalah air yang digunakan untuk keperluan seharihari yang kualitasnya memenuhi syarat kesehatan dan dapat diminum apabila telah dimasak. Air merupakan kebutuhan manusia yang sangat penting. Yang dimaksud dengan pengadaan air bersih adalah meliputi penyediaan sumber-sumbernya, pengolahan air menurut prinsip sanitasi, penyaluran kepada konsumen, maupun pengawasan kualitas airnya. Maka pengertian pengadaan air bersih adalah air bersih untuk memenuhi kebutuhan 
konsumsi keluarga (air minum). rumah tangga maupun umum (Slamet Ryadi, 1984) Air Permukaan Menurut Undang-undang No. 7 Tahun 2004 tentang sumber daya air menyartakan bahwa, air permukaan adalah semua air yang terdapat pada permukaan tanah. Air permukaan adalah air yang mengalir di permukaan bumi. Pada umumnya air permukaan ini akan mendapat pengotoran selama pengalirannya, misalnya oleh lumpur, batangbatang kayu, daun-daun, kotoran industri kota dan sebagainya. Beberapa pengotoran ini, untuk masingmasing air permukaan akan berbeda-beda, tergantung pada daerah pengaliran air permukaan ini. Jenis pengotorannya adalah merupakan kotoran fisik, kimia dan bakteriologi (Sutrisno, 2008). Menurut Chandra (2006) dalam bukuPengantar Kesehatan Lingkungan, air permukaan merupakan salah satu sumber penting bahan baku air bersih. Salah satu faktor yang dapat diperhatikan adalah Mutu atau kualitas air baku. Sumber air di permukaan biasanya mengandung bahan-bahan logam yang terlarut seperti $\mathrm{Na}, \mathrm{Mg}, \mathrm{Ca}$ dan $\mathrm{Fe}$ dalam jumlah tinggi yang disebut sebagai air sadah (Mandey, 2000).

Syarat-syarat air bersih Agar manusia tidak menerima akibat buruk dari penggunaan air, maka harus mengenal syarat-syarat air yang dapat digolongkan sebagai air bersih untuk memenuhi kebutuhan hidup sehari-hari.

Menurut Ichsan (1979) pada dasarnya air dikatakan bersih, apabila telah memenuhi 3 persyaratan, yaitu :

a) Syarat fisik, artinya air tersebut harus tidak berwarna (jernih), tidak berbau, tidak berasa, tidak keruh, mempunyai suhu di bawah udara setempat (segar)

b) Syarat-syarat bakteri, setelah melalui pemeriksaan, maka sekurang-kurangnya dalam $90 \%$ dari jumlah contoh air yang dikumpulkan tidak terdapat bakteri golongan coli

c) Syarat-syarat kimia, air tidak mengandung racun atau zat-zat mineral dalam jumlah terlalu banyak dan tidak boleh mengandung zat kimia yang dipergunakan dalam pengolahan dengan jumlah yang terlalu besar.

Berdasarkan zat kimia yang terlarut, perubahan pH. c. Pengamatan secara biologis, yaitu pengamatan pencemaran air berdasarkan mikroorganisme yang ada dalam air, terutama ada tidaknya bakteri patogen.

\section{Parameter Kualitas Air}

Air minum yang ideal seharusnya jernih, tidak berwarna, tidak berasa, dan tidak berbau. Air minum pun seharusnya tidak mengandung kuman patogen dan segala makhluk yang membahayakan bagi kesehatan manusia, dan tidak mengandung zat kimia yang dapat mengubah fungsi tubuh. Air seharusnya tidak korosif, tidak meninggalkan endapan pada seluruh jaringan distribusinya. Pada hakekatnya tujuan ini dibuat untuk mencegah terjadinya serta meluasnya penyakit bawaan air (Sumirat, 1994). Parameter pengukuran kualitas air selalu dibagi ke dalam beberapa bagian sebagai berikut :

a) Parameter fisis meliputi bau, kekeruhan, rasa, temperature dan warna

b) Parameter kimia meliputi : Air raksa $(\mathrm{Hg})$, Arsen (As), Barium (Ba), Cadmium (Cd), Khromium (Cr), Tembaga (cu, Sianida (Cn), Fluorida (F), Timbal $(\mathrm{Pb})$, Nitrat dan nitrit, Aluminium ( $\mathrm{Al})$. Khlorida (Cl), Kesadahan, Besi (Fe), Mangan (Mn), pH, Sulfat, Zat padat terlarut (TDS) dan Seng (Zn)

c) Parameter Biologis mencakup Coliform dan bakteri E Coli Lebih lanjut kualitas air bersih harus memenuhi kriteria berdasarkan Peraturan Menteri Kesehatan Republik Indonesia Nomor 416/MENKES/PER/IX/1990. tentang Syarat-syarat dan Pengawasan Kualitas Air

\section{SIMPULAN}

Peningkatan jumlah penduduk berpengaruh dalam aktivitas manusia yang dapat menghasilkan sampah semakin meningkat. Tamod (2009) menyatakan sampah kota yang ditimbun di tempat pemrosesan akhir (TPA), berpotensi menyebabkan pencemaran terhadap lingkungan baik pencamaran air permukaan dan air tanah maupun pencemaran tanah karena adanya air lindi. Permasalahan yang paling signifikan dari tempat pemrosesan akhir (TPA) sampah ini adalah lindi. Air Lindi dapat didefinisikan sebagai cairan yang timbul dari hasil dekomposisi biologis sampah yang telah membusuk yang mengalami pelarutan akibat masuknya air eksternal ke dalam timbunan sampah. Air lindi akibat proses degradasi sampah dari TPA merupakan sumber yang mempengaruhi perubahan sifat fisik, kimia maupun biologi (Husin dan Kustaman, 1992). Air lindi yang berada di permukaan tanah dapat menimbulkan polusi pada air tanah dan air permukaan (Ehrig, 1993). Pengelolaan sampah tanpa ada upaya pengurangan dan pendaur-ulangan sampah mengakibatkan kapasitas TPA dalam menampung sampah semakin berkurang.

\section{DAFTAR PUSTAKA}

Anonim, 2008. Planing For Municipal Solid Waste Management. www.Practicalaction.org. diunduh 20 juni 2008

Chandra, Budiman. 2006. Pengantar Kesehatan Lingkungan. EGC. Jakarta. 2007. Pengantar Kesehatan Lingkungan

Depkes RI, 1990. Peraturan Menteri Kesehatan RI No 416/Menkes/Per/IX/1990, Jakarta.

Ehrig, H. J. 1993. Quality and quantity of sanitary landfill air air lindi. Wastewater management research. Vol: 1. no 1.

Husin, Y.A. dan E. Kustaman. 1992. Metode dan Tehnik Analisis Kualitas Air. PPLH - Lembaga Penelitian IPB, Bogor. 
Ichsan, 1979. Kesehatan Lingkungan. Jakarta: PT. Rora Karya

Kawung, E. Tamod, Z. 2009. Tingkat Kelayakan Lahan TPA Sampah Kota Manado Dalam Ukuran Mitigasi Perencanaan Lokasi TPA. Jurnal Ilmiah Jurusan Sosiologi Fakultas ISIP \& Jurusan Tanah Fakultas Pertanian EKOTON Vol.9, No.1:1-10 April 2009. Manado: Fakultas ISIP Universitas Sam Ratulangi Manado \& Fakultas Pertanian Universitas Sam Ratulangi Manado.

Kepmen LH No. 51 Tahun 2004 Tentang Baku Mutu Air Laut.

Mahardika. 2010. Mendeteksi Dampak Polutan Sampah Terhadap Air Tanah Pemukiman Sekitar TPA Dengan Menggunakan Metode Geolistrik. Jurnal Universitas Negeri Malang. Malang

Mandey L.C 2000. Polusi air terhadap kesehatan. Kerjasama UNFPA dan CARE, Manado.

Maramis, A, 2008. Pengelolaan Sampah dan Turunannya di TPA, Alumni Program Pasca Sarjana Magister Biologi Terapan,Universitas Satyawacana, Salatiga.

Martono Djoko Heru, 1996, Pengendalian Air Kotor (Leachate) Dari Tempat Pembuangan Akhir (TPA) Sampah, Analisis Sistem Badan Pengkajian Penerapan Teknologi, Jakarta.

Purwendro, S. dan Nurhidayat., 2006. Mengolah Sampah untuk Pupuk Pestisida Organik. Penebar Swadaya, Jakarta.

Riyadi, Slamet. 1984. Pencemaran Air. Surabaya : Karya Anda.

Sanropie, D., Margono, Sugiharto .(1984). Pedoman Bidang Studi Penyediaan Air Bersih. Jakarta: Depkes RI.

Slamet Sumirat, 1996. Kesehatan Lingkungan. Yogyakarta: Gadjahmada University Press

Sutrisno, T., 2008, Tekhnologi Penyediaan Air Bersih, Cetakan kelima, Jakarta: Rineka Cipta. Hal: 23 70 1996,"Teknologi Penyediaan Air Bersih", Penerbit Rineka Cipta, Jakarta

Suryono dan Budiman (2010),Sistem 3R. Institut Teknologi Bandung

Tchobanoglous., 1993. Integrated Solid Waste Management Engineering Principles and Management Issues. McGraw Hill International Edition. New York.

Undang- undang No. 32 Tahun 2009. Tentang perlindungan dan pengelolaan lingkungan hidup http://www.slideshare.net/infos anitasi/uu-32tahun-2009- pengelolaan-lingkungan (diakses 1 September 2016)

Undang-undang Nomor 18 Tahun 2008 tentang : Pengelolaan Sampah, Jakarta.

Undang-Undang No.7 Tahun 2004 Tentang Sumber Daya Air 